\title{
Cloning of the human C5a anaphylatoxin receptor, and more
}

\author{
Norma P. Gerard ${ }^{1,2}$ and Craig Gerard ${ }^{1 *}$ \\ ${ }^{1}$ Ina Sue Perlmutter Laboratory, Division of Respiratory Diseases, Department of Medicine, Children's Hospital, Harvard Medical \\ School, Boston, MA, USA, ${ }^{2}$ Department of Medicine, Beth Israel Deaconess Medical Center, Boston, MA, USA
}

Keywords: C5aR/C5R1, 7-TMS receptors, complement anaphylatoxin, C5a, G protein coupled receptor

OPEN ACCESS

Edited by:

Bernhard Moser,

Cardiff University, UK

Reviewed by:

Israel Charo,

ChemoCentryx, Inc., USA

*Correspondence:

Craig Gerard

craig.gerard@childrens.harvard.edu

Specialty section:

This article was submitted to Chemoattractants, a section of the journal Frontiers in Immunology

Received: 29 June 2015 Accepted: 17 August 2015 Published: 01 September 2015

Citation:

Gerard NP and Gerard C (2015)

Cloning of the human C5a

anaphylatoxin receptor, and more.

Front. Immunol. 6:445.

doi: 10.3389/fimmu.2015.00445
The initial observation in 1973 that the complement C5 activation product, C5a, has the ability to stimulate human neutrophils led to the concept of a specific C5a receptor (1). In the mid1986, a groundbreaking paper published in Nature announced the cloning of the beta-adrenergic receptor, and for the first time established seven transmembrane (7TM) G protein-coupled receptors as members of the rhodopsin superfamily (2). Almost simultaneously, Feltner and colleagues demonstrated that the FMLP, C5a, and LTB4 activities on rabbit neutrophils could be inhibited by pertussis toxin, indicating coupling to GTP binding proteins (3). In 1987, Masu and colleagues used an oocyte expression cloning system to isolate a cDNA encoding the neuropeptide substance $\mathrm{K}$ receptor; and later, the same group identified the related substance $\mathrm{P}$ receptor $(4,5)$.

In 1989, we realized that the pertussis sensitivity of the fMLP, C5a, and LTB4 receptors suggested that they would also be members of the rhodopsin superfamily. When we aligned the handful of structures for the then known 7TM receptors (adrenergic, serotonin, dopamine, FSH/LH, and substance $\mathrm{P}$ and $\mathrm{K}$ receptors), we recognized homologies in both the transmembrane segments and intracellular loops, which presumably facilitated interactions with $G$ proteins. This observation actually presented us with an opportunity to attempt to clone receptors by homology to the superfamily as "orphan receptors."

We constructed an antisense oligonucleotide with minimal degeneracy that encompassed a highly conserved NPXXY motif in the seventh transmembrane segment of the known rhodopsin family members. In order to enrich in C5a receptors, we took advantage of the fact that the receptors were induced by cyclic-AMP in U937 cells, and in retinoic acid differentiated human HL60 cells. By summer of 1990, we had isolated 20 cDNAs using this approach from the cAMP induced U937 cell library. About half of these clones were an identical cDNA that we named NPIIY-18. Using this as a probe, we demonstrated that NPIIY-18 recognized a $\sim 2.2 \mathrm{~kb}$ mRNA only in cAMP differentiated U937 cells. Northern blot analyses showed that NPIIY-18 was present only in cells known to express the C5a receptor. As NPIIY-18 was not a full-length cDNA, we then probed the retinoic acid differentiated HL60 cell library. We isolated a full-length DNA from this library that encoded a 7TM receptor with $25 \%$ homology to the substance $\mathrm{K}$ receptor and $35 \%$ homology to the human fMLP receptor (FPR1), which was cloned by Francois Boulay in May 1990 (6). When expressed in COS cells, we showed that NPIIY-18 encoded a high-affinity receptor for human C5a (Figure 1) (7). This work was accepted for publication in Nature in December 1990. In the summary paragraph of this manuscript, we pointed out that our approach should be helpful to clone the receptors for the leukotrienes, platelet activating factor, interleukin-8, and adenosine receptors as these are all present on cAMP differentiated U937 cells. Almost simultaneously, Francois Boulay confirmed our identification of the human $\mathrm{C} 5 \mathrm{aR}$, which his group accomplished by expression cloning of differentiated HL-60 cells (8). His work was published in March 1991, some 4 months after ours.

In November 1990, within months of the identification of the human FPR1, Thomas et al. reported the cloning of the rabbit receptor for fMLP, F3R (9), which had almost no significant homology to the human receptor. This was troubling, because we knew that when the ligand 


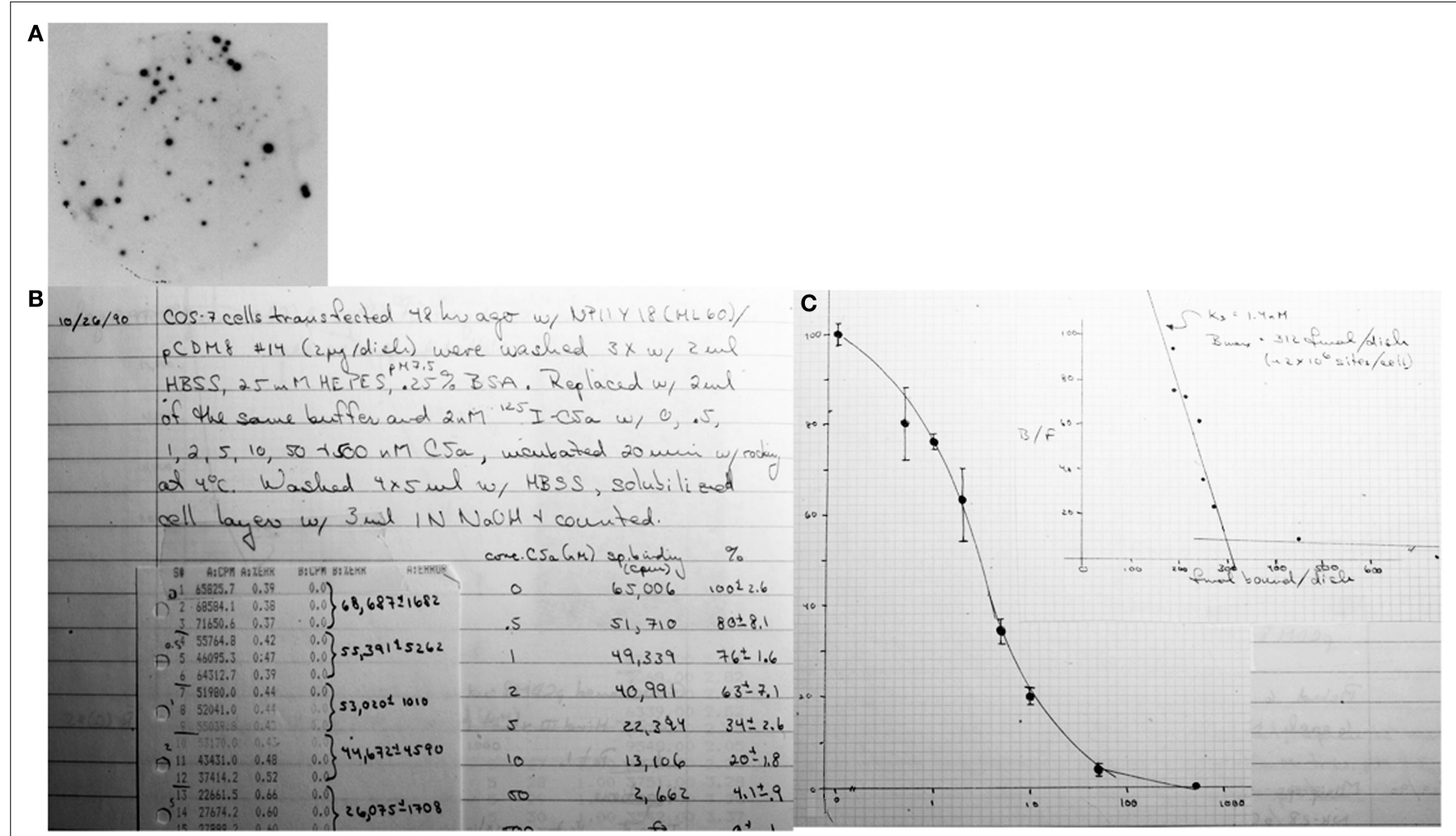

FIGURE 1 | Final steps in cloning and identifying the human C5a receptor. (A) Tertiary screen of clone NPIIY-18 using ${ }^{32}$ P-labeled oligonucleotide probe. (B) NPIIY-18 was transfected into COS7 cells and tested for binding of ${ }^{125} \mathrm{I}-\mathrm{C} 5 \mathrm{a}$ under competitive binding conditions. (C) The resulting binding isotherm and Scatchard analysis proving the clone's identity.

was identical from species to species, the receptors were generally highly conserved. Thus, the adrenergic, dopamine, serotonin, and histamine receptors are $>90 \%$ identical across species. Curiously, the cDNA was reported to bind the FPR1 radioligand and transduce calcium transients. Because the expression of the claimed rabbit F3R formyl peptide receptor was restricted to neutrophils, we wondered if, in fact, the Navarro lab had misidentified an interleukin-8 receptor. One of us (Craig Gerard) actually traveled to the Navarro lab to obtain the F3R cDNA to establish a collaboration and test its identity as a receptor for IL-8. At that time, there was no radioligand IL-8 commercially available. Henry Showell, of Pfizer Central Research, was able to provide us with a custom iodinated IL-8, which we demonstrated to bind F3R. Unfortunately, we did not have sufficient quantities of the reagent to perform comprehensive studies to publish our findings. We disclosed our result to Javier Navarro, but were left in silence. Unbeknownst to us, Dan Witt, at Repligen, had reportedly approached the Navarro lab with a similar idea. Thomas et al. went on to publish F3R as an IL8 receptor, without retracting the previous paper (10). During this time, Tom Schall and I met at a FASEB meeting with Phil Murphy, and suggested to him that he use F3R to clone a human homolog from HL60 cells and test it against IL8. The

\section{References}

1. Goldstein I, Hoffstein S, Gallin J, Weissmann G. Mechanisms of lysosomal enzyme release from human leukocytes: microtubule assembly and membrane landmark Murphy and Tiffany paper resulted (11). Phil offered one of us (Craig Gerard) coauthorship for the helpful suggestion but because of intellectual property concerns at our institution, we requested an acknowledgment instead.

Over the next decade, the orphan receptor approach led to the identification of a wide variety of chemoattractant receptors, including most of the chemokine receptor system. The most notable events in the area of chemokines occurred when CXCR4 and CCR5 were identified as HIV coreceptors. It was known from the work of Ed Berger that CXCR4 was the obligate coreceptor with $\mathrm{CD} 4$ for laboratory-adapted strains of HIV (12). However, the wild type, the so-called macrophage tropic strain used an unknown coreceptor. In December 1995, it was reported in the New York Times that the Gallo laboratory had identified Mip1 $\alpha$, Mip1 $\beta$, and RANTES as substances that inhibited HIV infections (13). Coincidentally, at the Fourth International Chemokine Symposium, held June 27-30, 1995, Izzy Charo described an orphan receptor identified as CCR5, linked to CCR2, which bound Mip1 $\alpha$, Mip1 $\beta$, and RANTES (14). Thus, an international race began as five chemokine labs partnered with HIV labs to prove the hypothesis that CCR5 was the HIV coreceptor.

fusion induced by a component of complement. Proc Natl Acad Sci U S A (1973) 70:2916-20. doi:10.1073/pnas.70.10.2916

2. Dixon RA, Kobilka BK, Strader DJ, Benovic JL, Dohlman HG, Frielle $\mathrm{T}$, et al. Cloning of the gene and cDNA for mammalian beta-adrenergic 
receptor and homology with rhodopsin. Nature (1986) 321:75-9. doi:10.1038/ $321075 \mathrm{a} 0$

3. Feltner DE, Smith RH, Marasco WA. Characterization of the plasma membrane bound GTPase from rabbit neutrophils. I. Evidence for an Ni-like protein coupled to the formyl peptide, C5a, and leukotriene B4 chemotaxis receptors. J Immunol (1986) 137:1961-70.

4. Masu Y, Nakayama K, Tamaki H, Harada Y, Kuno M, Nakanishi S. cDNA cloning of bovine substance-K receptor through oocyte expression system. Nature (1987) 329:836-8. doi:10.1038/329836a0

5. Yokota Y, Sasai Y, Tanaka K, Fujiwara T, Tsuchida K, Shigemoto R, et al. Molecular characterization of a functional cDNA for rat substance $\mathrm{P}$ receptor. J Biol Chem (1989) 264:17649-52.

6. Boulay F, Tardif M, Brouchon L, Vignais P. The human N-formylpeptide receptor. Characterization of two cDNA isolates and evidence for a new subfamily of G-protein-coupled receptors. Biochemistry (1990) 29:11123-33. doi:10.1021/ bi00502a016

7. Gerard NP, Gerard C. The chemotactic receptor for human C5a anaphylatoxin. Nature (1991) 349:614-7. doi:10.1038/349614a0

8. Boulay F, Mery L, Tardif M, Brouchon L, Vignais P. Expression cloning of a receptor for C5a anaphylatoxin on differentiated HL-60 cells. Biochemistry (1991) 30:2993-9. doi:10.1021/bi00226a002

9. Thomas KM, Pyun HY, Navarro J. Molecular cloning of the fMet-Leu-Phe receptor from neutrophils. J Biol Chem (1990) 265:20061-4.

10. Thomas KM, Taylor L, Navarro J. The interleukin-8 receptor is encoded by a neutrophil-specific cDNA clone, F3R. J Biol Chem (1991) 266:14839-41.
11. Murphy PM, Tiffany HL. Cloning of complementary DNA encoding a functional human interleukin-8 receptor. Science (1991) 253:1280-3. doi:10.1126/ science. 1891716

12. Feng Y, Broder CC, Kennedy PE, Berger EA. HIV-1 entry cofactor: functional cDNA cloning of a seven-transmembrane, G protein-coupled receptor. Science (1996) 272:872-7. doi:10.1126/science.272.5263.872

13. Cocchi F, DeVico AL, Garzino-Demo A, Arya SK, Gallo RC, Lusso P. Identification of RANTES, MIP-1 alpha, and MIP-1 beta as the major HIV-suppressive factors produced by CD8+ T cells. Science (1995) 270:1811-5. doi:10.1126/ science.270.5243.1811

14. Raport CJ, Gosling J, Schweickart VL, Gray PW, Charo IF. Molecular cloning and functional characterization of a novel human CC chemokine receptor (CCR5) for RANTES, MIP-1beta, and MIP-1alpha. J Biol Chem (1996) 271:17161-6. doi:10.1074/jbc.271.29.17161

Conflict of Interest Statement: The authors declare that the research was conducted in the absence of any commercial or financial relationships that could be construed as a potential conflict of interest.

Copyright (C) 2015 Gerard and Gerard. This is an open-access article distributed under the terms of the Creative Commons Attribution License (CC BY). The use, distribution or reproduction in other forums is permitted, provided the original author(s) or licensor are credited and that the original publication in this journal is cited, in accordance with accepted academic practice. No use, distribution or reproduction is permitted which does not comply with these terms. 